\title{
PERANAN CUMI-CUMI BAGI KESEHATAN
}

\author{
Oleh \\ Diah Anggraini Wulandari ${ }^{1)}$
}

\begin{abstract}
THE BENEFITS AND ROLE OF SQUID FOR HEALTH. Squids are rich in protein with a protein content 15-20\%. Squids containing macro and micro minerals such as sodium, potassium, phosphorus, calcium, magnesium and selenium, besides that squid also comprise essential amino acids such as tryptophan, threonine, methionine, lysine, leucine, isoleucine, valine, phenylalanine, and non-essential amino acids such as glutamic acid, aspartic acid, tyrosine, cysteine, serine, proline, glycine, arginine and histidine. Squid ink contain alkaloids that potential as anti-inflammatory, antihypertensive, anti-diabetic, anti-microbial and anti-malaria agents. The benefit of Squids in the food industry are an enhancer of flavor and an artificial leather constituent in the biomedical field.
\end{abstract}

\section{PENDAHULUAN}

Indonesia merupakan negara maritim terbesar di dunia dengan hasil laut yang melimpah, nilai ekspor perikanan dari tahun ke tahun semakin meningkat, hal ini didukung dengan peningkatan jumlah nilai ekspor tahun 2017 naik sebesar 8,12\% dari tahun sebelumnya USD 3,78 miliar pada tahun 2016 menjadi USD 4,09 miliar pada tahun 2017 (Ditjen PSDKP, 2018). Salah satu produk unggulan ekspor perikanan yaitu kelompok Cephalopoda (cumi, sotong, gurita). Jumlah ekspor produk Cephalopoda (cumi, sotong, gurita) pada tahun 2015 sebesar USD 181,98 juta, kemudian pada tahun 2016 sekitar USD 294,14 juta, dan meningkat menjadi USD 310 juta pada tahun 2017 (BPS, 2018).

Cumi-cumi merupakan salah satu jenis makanan yang sering dikonsumsi oleh masyarakat Indonesia. Tingkat konsumsi masyarakat terhadap makanan yang berasal dari laut seperti cumi-cumi semakin meningkat, seiring dengan meningkatnya kesadaran masyarakat akan pentingnya pemenuhan nutrisi bagi tubuh. Menurut data Kementerian Kelautan dan Perikanan (2013), konsumsi produk perikanan termasuk cumi-cumi mengalami kenaikan ratarata sebesar 5,21\%. Konsumsi makanan seseorang berpengaruh terhadap status gizi. Status gizi baik atau optimal terjadi bila tubuh memperoleh cukup zat gizi yang digunakan secara efisien, sehingga memungkinkan pertumbuhan fisik, perkembangan otak, kemampuan kerja, dan kesehatan secara umum. Kurang gizi pada usia muda dapat berpengaruh pada perkembangan mental, kemampuan berpikir, dan menyebabkan ganguan otak secara permanen (Almatsier, 2002).

\footnotetext{
$\overline{{ }^{1)} \text { Pusat Penelitian Oseanografi, LIPI }}$
} 
Cumi-cumi memiliki kandungan gizi yang cukup lengkap antara lain mengadung protein, asam amino esensial dan nonesensial serta vitamin yang bermanfaat bagi tubuh. Kandungan protein pada cumi-cumi berkisar antara 15-20\% (Mukholik, 1995). Meskipun nilai konsumsi cumi-cumi semakin meningkat namun beberapa kalangan masyarakat masih saja ada yang enggan untuk mengkonsumsi cumi-cumi. Hal ini disebabkan kurangnya pengetahuan masyarakat terkait kandungan gizi dan manfaat cumi - cumi bagi kesehatan. Mengingat keterbatasan informasi tersebut maka perlu adanya informasi lebih lanjut mengenai kandungan gizi, peranan dan manfaat nya bagi kesehatan sehingga dapat meningkatkan kesadaran masyarakat dalam mengkonsumsi protein hewani yang berasal dari laut khususnya cumi-cumi.

\section{KANDUNGAN GIZI CUMI-CUMI}

Selain mengandung protein yang tinggi, cumi-cumi juga mengandung asam amino penting dan mineral seperti natrium, kalium, fosfor, kalsium, magnesium, dan selenium. Cumi-cumi juga merupakan sumber vitamin seperti vitamin B1 (tiamin), B2 (ribofavin), $\mathrm{B} 12$, niasin, asam folat, serta vitamin larut lemak (A, D, E, K) (Ensminger et al., 1995). Secara rinci kandungan gizi beberapa jenis cumi-cumi dapat dilihat pada Gambar 1.

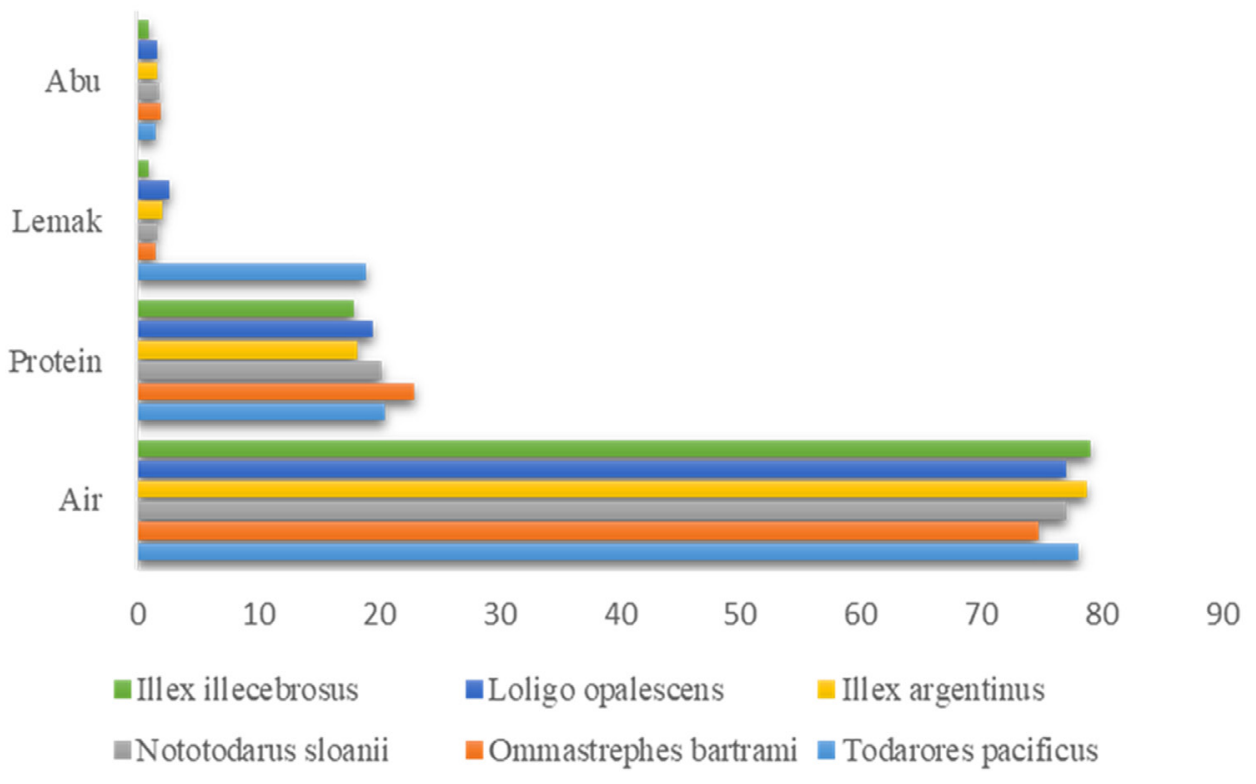

Gambar 1. Kandungan gizi beberapa jenis cumi-cumi (Kreuzer dalam Sudjoko, 1988). 
Cumi-cumi merupakan sumber protein hewani yang berasal dari laut. Hasil penelitian Kreuzer dalam Sudjoko (1988) kandungan protein cumi-cumi berkisar antara 18-23\%, dengan kadar protein tertinggi terdapat pada cumicumi jenis Ommastrephes bartrami. Kandungan lemak cumi-cumi berkisar antara 1-3\%, sedangkan kadar abunya adalah berkisar antara 1-2\%. Penelitian lain dari Santoso et al. (2014) . yang membandingkan komposisi kimia cumi-cumi dengan udang vannamei menunjukkan bahwa kadar protein cumicumi yaitu $14,65 \%$. dan udang vannamei $17,43 \%$, sedangkan komposisi kadar lemak cumi-cumi $0,24 \%$ dan udang vannamei yaitu $0,15 \%$. Perbandingan komposisi kimia cumi-cumi dan udang vannamei dapat dilihat pada Gambar 2.

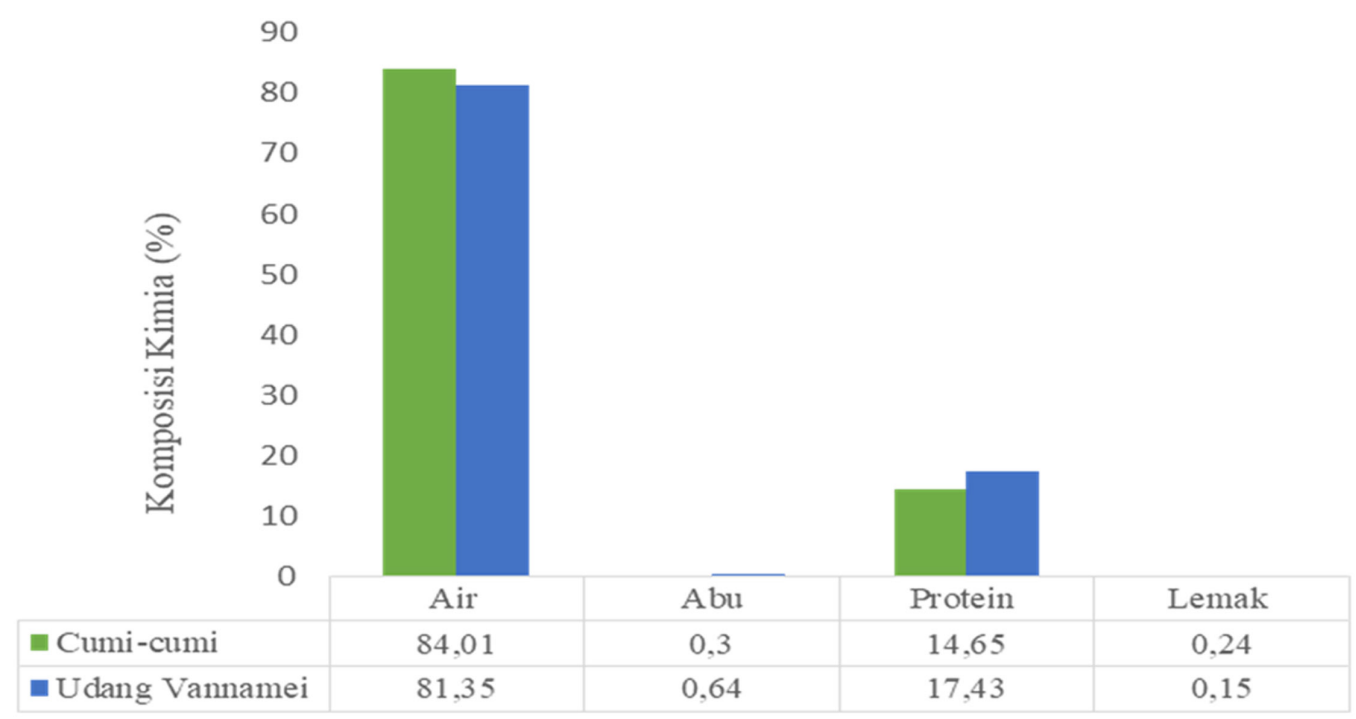

Gambar 2. Komposisi kimia cumi-cumi dan udang vannamei (Santoso et al., 2014) .

Hasil penelitian lain Okuzumi \& Fujii (2000) menunjukkan bahwa kisaran kandungan gizi cumi-cumi meliputi kadar air $(78,1-82,2 \%)$, abu $(1,2-1,7 \%)$, protein $(14-16 \%)$, dan lemak $(1-2 \%)$. Selanjutnya apabila dibandingkan dengan hasil penelitian Santoso et al.
(2014) maka kandungan air, abu, protein dan lemak pada cumi-cumi tidak jauh berbeda. Komposisi mineral makro dan mikro pada cumi-cumi dan udang vannamei secara rinci dapat dilihat pada Gambar 3. 


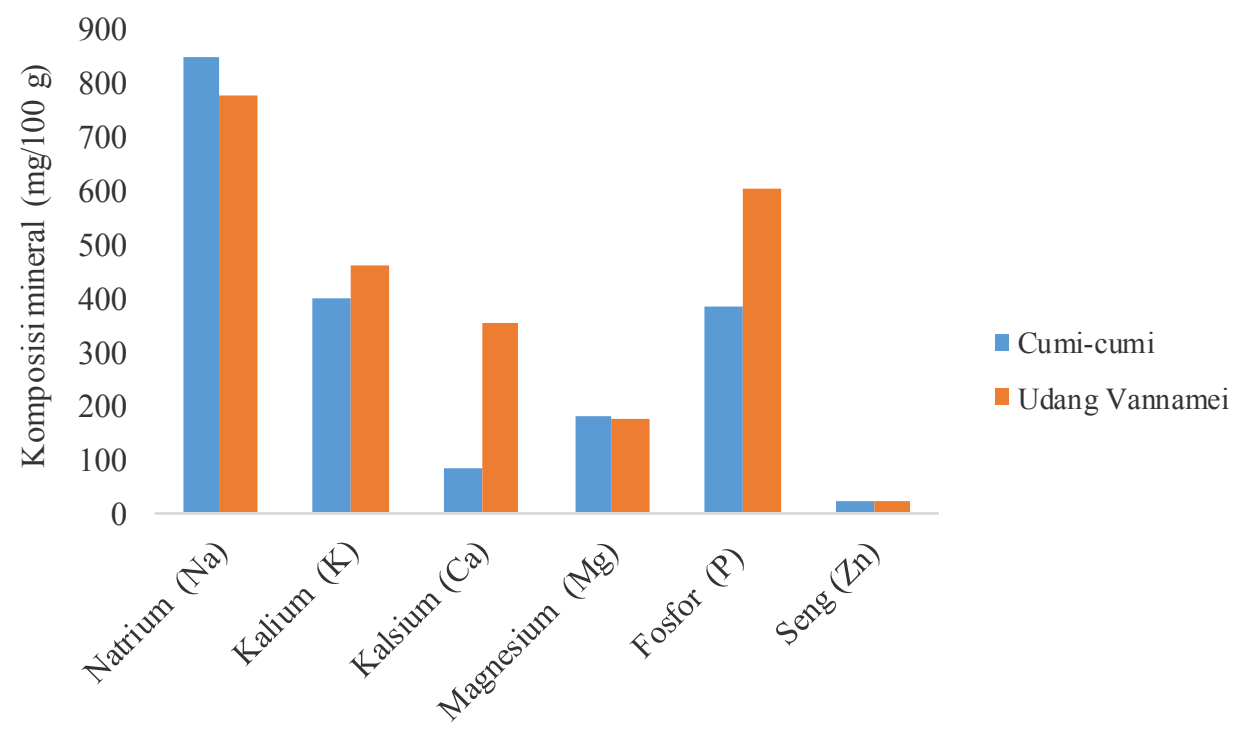

Gambar 3. Komposisi mineral pada cumi-cumi dan udang vannamei (Santoso et al., 2014).

Cumi-cumi juga mengandung mineral penting seperti natrium, kalium, kalsium, magnesium, fosfor, seng, dan iodum yang bermanfaat bagi tubuh. Fosfor dan kalsium berguna untuk pertumbuhan kerangka tulang, sehingga sangat baik untuk pertumbuhan anakanak dan untuk mencegah osteoporosis di masa tua (Almatsier, 2006). Hasil penelitian Santoso et al., (2014) menunjukkan bahwa kandungan mineral makro tertinggi pada cumi-cumi yaitu natrium $848,63 \mathrm{mg} / 100 \mathrm{~g}$ lebih tinggi dibandingkan udang vannamei yaitu $777,45 \mathrm{mg} / 100 \mathrm{~g}$, sedangkan komposisi mineral mikro terendah pada cumi-cumi yaitu kalsium 83,03 mg/100g. Komposisi kalsium pada udang vannamei yaitu $354,28 \mathrm{mg} / 100 \mathrm{~g}$. Rendahnya kandungan kalsium pada cumi-cumi disebabkan cumi-cumi tidak memiliki cangkang luar sebagai sumber kalsium sedangkan sumber kalsium pada udang vannamei berasal dari karapasnya.

Selain memiliki beberapa jenis mineral mikro dan makro, cumi-cumi juga memiliki 18 jenis asam amino penting yang bermanfaat bagi tubuh. Kandungan asam amino tertinggi terdapat pada asam glutamat yaitu 2,12 $\mathrm{g} / 100 \mathrm{~g}$, asam aspartat $1,503 \mathrm{~g} / 100 \mathrm{~g}$, arginin $1,136 \mathrm{~g} / 100 \mathrm{~g}$, dan lisin 1,164 $\mathrm{g} / 100 \mathrm{~g}$, sedangkan cumi-cumi memiliki kandungan asam amino terendah pada histidin dan triptofan. Asam glutamat berfungsi untuk merangsang syaraf pada lidah manusia, dan umumnya glutamat tersebut dimanfaatkan dalam industri penyedap rasa. Asam aspartat berfungsi sebagai pembangkit neurotransmiter di otak dan saraf otot, selain itu aspartat juga berperan dalam menjaga daya tahan tubuh (Almatsier, 2006). Komposisi asam amino protein cumi-cumi secara jelas dan terperinci dapat dilihat pada Gambar 4. 


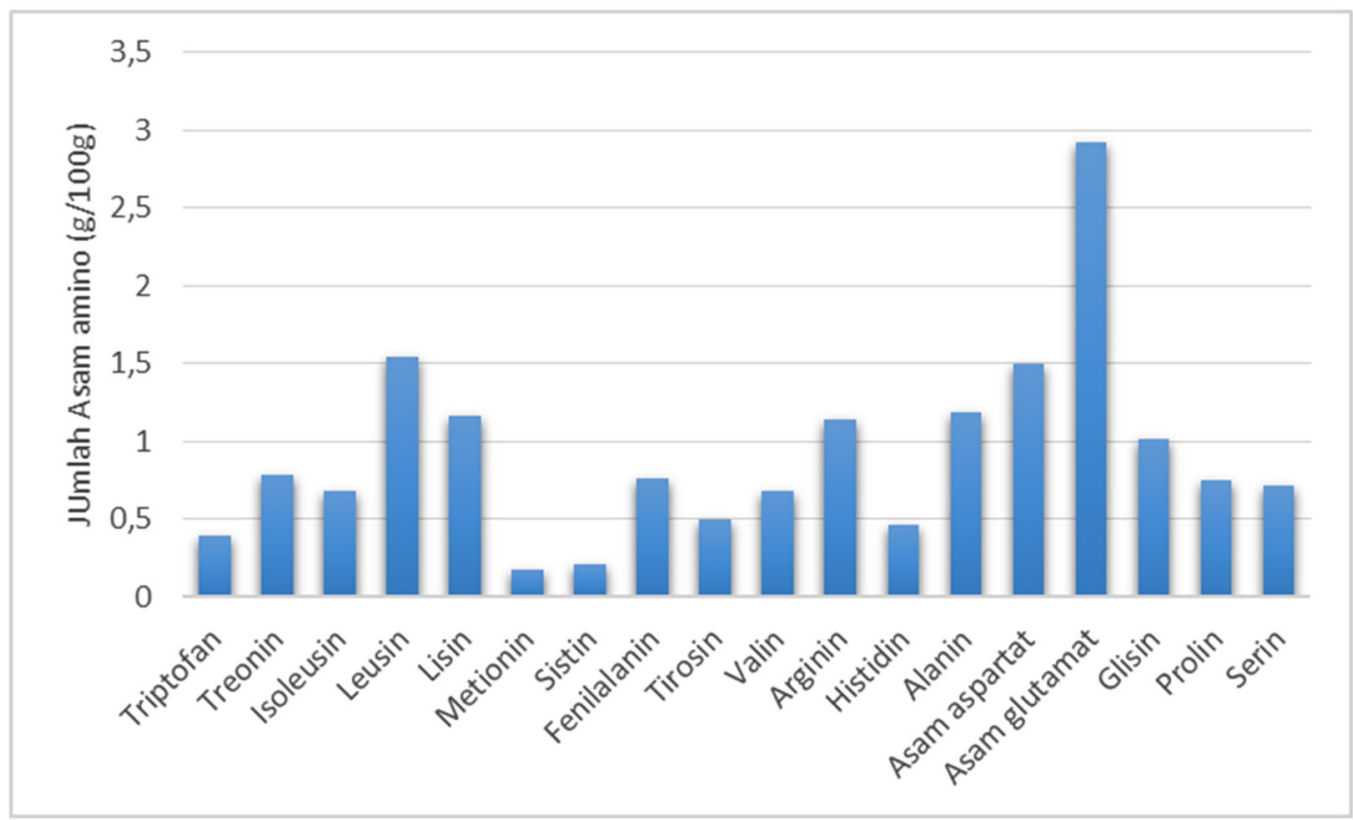

Gambar 4. Komposisi asam amino protein cumi-cumi Uroteuthis duvauceli (Remyakumari et al., 2018).

Asam amino terdiri atas unsur-unsur karbon, hidrogen, oksigen, dan nitrogen. Ada beberapa asam amino mengandung unsur-unsur fosfor, besi, iodium, dan cobalt. Asam amino dibagi menjadi asam amino esensial dan nonesensial yang berfungsi untuk membangun sel jaringan tubuh, mengganti sel-sel tubuh yang rusak, menjaga keseimbangan asam basa dari cairan tubuh, membuat protein darah, pemberi kalori pada tubuh, dan menurunkan kadar kolesterol darah hingga 35\% (Almatsier, 2002).

Asam amino esensial adalah asam amino yang tidak bisa diproduksi sendiri oleh tubuh sehingga harus didapatkan dari konsumsi makanan. Jenis-jenis asam amino esensial yaitu triptofan, treonin, metionin, lisin, leusin, isoleusin, fenilalanin dan valin.
Sedangkan asam amino nonesensial adalah asam amino yang bisa diproduksi sendiri oleh tubuh, sehingga memiliki prioritas konsumsi yang lebih rendah dibandingkan dengan asam amino esensial. Asam amino nonesensial yang diproduksi oleh tubuh antara lain adalah tirosin, sistein, serin, prolin, glisin, asam glutamat, asam aspartat, arginin, alanin, histidin, glutamin (Almatsier, 2002).

\section{PERAN DAN MANFAAT TINTA CUMI-CUMI}

Cumi-cumi merupakan produk unggulan ekspor Indonesia yang dikonsumsi dan dimanfaatkan dalam berbagai industri (Agusandi et al., 2013). Karakteristik dari cumi-cumi yaitu adanya kantung tinta yang terdapat di atas usus besar dan bermuara di dekat anus. Bila 
cumi-cumi diserang musuh, kantung tinta akan berkontraksi melalui pipa. Hal ini menyebabkan pembentukan awan hitam di sekililingnya yang memungkinkan cumi-cumi terhindar dari serangan musuh. Metabolit sekunder pada cumicumi berasal dari tinta yang diproduksi sebagai bentuk pertahanan diri terhadap musuhnya. Selama ini tinta cumi-cumi belum banyak dimanfaatkan padahal didalam tinta cumi-cumi mengandung protein sekitar 10,88\% (Sasaki et al., 1997). Metabolit sekunder yaitu metabolit yang tidak memiliki fungsi untuk pertumbuhan dan perkembangan secara langsung dan diproduksi pada kondisi tertentu (Hanson, 2011). Berdasarkan asal usul biosintesisnya dibagi menjadi empat kelompok yaitu: alkaloid, fenilpropanoid, poliketida dan terpenoid (Springob \& kuntchen, 2009).

Tinta cumi-cumi bersifat alkaloid, sehingga tidak disukai oleh predator, terutama ikan. Alkaloid merupakan kelompok terbesar dari metabolit sekunder yang beratom nitrogen dan bersifat basa. Beberapa jenis alkaloid memiliki manfaat dalam pengobatan antara lain sebagai antiinflamasi, antihipertensi, antidiare, antidiabetes, antimikroba dan antimalaria, tetapi beberapa senyawa golongan alkaloid bersifat racun (Wink, 2008). Selain itu tinta cumi-cumi ini mengandung butirbutir melanin atau pigmen hitam. Melanin alami adalah melanoprotein yang mengandung $10-15 \%$ protein, sehingga menjadi salah satu sumber protein yang sama baiknya dengan kandungan protein pada daging (Astawan, 2008).
Tinta cumi-cumi maupun tinta sotong mengandung melanin, protein, lemak, glikosaminoglikan dan asam amino esensial berupa lisin, leusin, arginin, dan fenilalanin (Agusandi et al., 2013). Tinta cumi-cumi dapat berperan sebagai obat pelindung sel pada pengobatan kanker dengan cara kemoterapi, melalui peningkatan jumlah sel leukosit dan sel nukleat sum-sum tulang, yang jumlahnya menurun akibat penggunaan obat pembunuh sel tumor tersebut. Melanin dari tinta cumi-cumi mempunyai aktivitas anti tumor dengan menghambat aktivitas plasmin untuk meningkatkan thromboxan dan meningkatkan sistem imun untuk membunuh sel kanker (Zhong et al., 2009). Melanin juga berperan sebagai antioksidan (Lei et al., 2007a), anti radiasi (Lei et al., 2007b), dan antirotavirus (Rajaganapathi et al., 2007). Di Jepang tinta cumi-cumi digunakan sebagai bahan peningkat cita rasa (Flavor). Selain itu, dari hasil Penelitian Razak (2013) mengungkapkan bahwa kandungan cangkang cumi-cumi mengandung $100 \%$ unsur $\mathrm{C}$ atau karbon. Hal ini berpotensi sebagai penyusun kulit buatan. Material tersebut berpotensi bagi aplikasi biomedik berupa pengembangan plastik untuk implant dan karbon fiber karena kuat dan ringan.

Konsumsi cumi-cumi berlebihan dapat menimbulkan efek kurang baik bagi tubuh. Hal ini disebabkan cumi mengandung kolesterol yang cukup tinggi. Hasil penelitian Saidin (2000) menunjukkan bahwa kandungan kolesterol pada cumi-cumi yaitu 159 $\mathrm{mg} / 100 \mathrm{~g}$, setara dengan udang 161 
$\mathrm{mg} / 100$ dan lebih tinggi dibandingkan kolesterol pada ayam broiler maupun ayam kampung berturut-turut yaitu sebesar $110 \mathrm{mg} / 100 \mathrm{~g}$ dan $116 \mathrm{mg} / 100 \mathrm{~g}$. Kandungan Kolesterol yang tinggi dapat memicu timbulnya berbagai macam penyakit salah satunya adalah penyakit jantung koroner (Salim et al., 2016).

\section{BIOLUMINESENSI}

Cumi-cumi juga memiliki kemampuan untuk memancarkan cahaya yang disebut bioluminesensi. Bioluminesensi adalah suatu penomena pancaran cahaya tanpa mengeluarkan panas melalui proses reaksi kimia pada suatu organ organisme hidup. Pancaran cahaya tersebut dapat dijumpai pada beberapa kelompok organisme yaitu: bakteri, jamur, plankton (algae), insekta (serangga), invertebrata (cumi/ cephalopoda) dan vertebrata (ikan) (Hasting \& Morin, 1989), sedangkan peranan pancaran cahayanya berbeda untuk masing-masing organisme. Herring, (1977) menyatakan bahwa fungsi organ cahaya yang terdapat pada hewan cephalopoda, yaitu berfungsi untuk penyamaran dirinya, membingungkan dan menyilaukan lawannya serta komunikasi dengan hewan lainnya.

\section{PENUTUP}

Pemanfaatan cumi-cumi di Indonesia masih sangat terbatas pada ekspor bahan baku dalam bentuk segar, kering, dan beku. Namun di negara lain seperti Jepang cumi telah dimanfaatkan sebagai bahan baku industri pangan untuk peningkat cita rasa yang berfungsi bagi kesehatan. Selain itu, cumi-cumi berpotensi sebagai penyusun kulit buatan dalam aplikasi biomedik berupa plastik untuk implan dan karbon fiber karena bersifat kuat dan ringan. Cumi-cumi mengandung metabolit sekunder yang bermanfaat sebagai bahan baku obat seperti antiinflamasi, antihipertensi, antidiabetes, dan antimikroba, Pengembangan sektor perikanan khususnya cumi-cumi di Indonesia diharapkan bukan hanya sekedar sebagai bahan baku pangan melainkan juga dapat diaplikasikan sebagai bahan baku industri biomedik, farmaseutikal, nutraseutikal yang bermanfaat bagi kesehatan.

\section{DAFTAR PUSTAKA}

Almatsier, S. 2002. Prinsip Dasar Ilmu Gizi. Gramedia Pustaka. Jakarta: 338 hlm.

Almatsier, S. 2006. Prinsip Dasar Ilmu dan Gizi. Cetakan Keenam. Gramedia. Jakarta: 334 hlm.

Agusandi, Supriadi, A, dan Lestari, D. L. 2013. Pengaruh penambahan tinta cumi-cumi (Loligo $s p$ ) terhadap kualitas nutrisi dan penerimaan sensoris mi basah. Fishtech. 2(1) : 22-37.

Astawan, M. 2008. Khasiat WarnaWarni Makanan. Gramedia Pustaka Utama. Jakarta: 320 hlm.

[BPS]. Badan Pusat Statistik. 2018. Data Ekspor Cumi, Sotong, Gurita (CSG). www.bps.go.id 
. Diakses pada tanggal 22 Juni 2018.

Ensminger, A. H. M. E. Ensminger, J. E. Konlande, and J. R. K. Robson. 1995. The Concise Encyclopedia of Foods and Nutrition. CRC Press, Boca Raton Florida: 114-128 hlm.

Hanson, J. R. 2011. Natural Products: The Secondary Metabolites. University of Sussex. UK: 312 hlm.

Hasting, J. W. and J. Morin. 1989. Bioliminescence, in Neural and Integrative Animal Physiology, C. Ladd. Prosser, Editor, WileyLiss, New York: 131-168 hlm.

[KKP]. Kementerian Kelautan dan Perikanan Republik Indonesia. 2018. Statistik Ekspor Perikanan. Direktorat Jendral Pengawasan Sumberdaya Kelautan dan Perikanan. www. kkp.go.id. Diakses pada tanggal 22 Juni 2018.

[KKP]. Kementerian Kelautan dan Perikanan Republik Indonesia. 2013. Statistik Ekspor Perikanan 2013, 2012, dan 2011. Direktorat Jendral Pengolahan dan Pemasaran Hasil Perikanan. www.kkp. go.id. Diakses pada tanggal 22 Juni 2018.

[KKP]. Kementerian Kelautan dan Perikanan. 2011. Informasi Cumi-cumi. Direktorat prasarana Perikanan Tangkap.
Departemen Kelautan dan Perikanan Jakarta. www.kkp. go.id. Diakses pada tanggal 15 Juni 2018.

Mukholik. 1995. Pengaruh larutan tinta cumi -cumi dan suhu perebusan terhadap air rebusan cumi-cumi. [Skripsi]. Institut Pertanian Bogor.

Lei, M. J. F. Wang, L. Pang, Y. M. Wang, S. G. Chen, and C. H. Xue. 2007a. Effects of Sepia on the metabolization of blood lipid and antioxidant ability in hyperlipidemia rats. The Chinese Journalof Marine Drugs. 3(1): 30-33.

Lei M. J. F. Wang, Y. M. Wang, L. Pang, Y. Wang, W. Xu, and C. H. Xue. 2007b. Study of theradioprotective effect of cuttlefish ink on hemopoietic injury. Asia Pacific Journal of Clinical Nutrition. 16(1): 239-243.

Lei M, C. H . Xue, Y. M. Wang, Z. J. Li, Y. Xue, and J. F. Wang. 2008 Effect of squid ink melanin$\mathrm{Fe}$ on iron deficiency anemia remission. Journal of Food Science. 73(8): 207-211.

Okuzumi, M and T. Fujii. 2000. Nutritional and Functional Properties of Squid and Cuttlefish. National Cooperative Association of Squid Processors, Tokyo: 379 hlm.

Rajaganapathi, J. S. P. Thyagarajam, and J. K. Edward. 2007. Study 
on cephalopod's ink for antiretroviral activity. Indian Journal of Experimental Biology. 38(1): 519-520.

Razak, A. 2013. Potensi cephalopoda sebagai biomaterial baru. Prosiding semirata FMIPA Universitas Lampung. 40 (1): 15-27.

Remyakumari, K. R. J. Gibson, K.K. Ajeeshkumar, Kuwishnu, K.K. Asha, and M. Susseela. 2018. Biochemical profile and nutritional quality of Indian squid Uretheuthis duvauceli. International Journal Fisheries and aquatic Studies. 6(3): 187192.

Salim, F. A. Arifin, dan M. Asnawati. 2016. Korelasi antara kadar kolesterol total dengan jumlah monosit pada pasien penyakit jantung koroner. Berkala kedokteran 12(1): 95-101.

Saidin, M. 2000. Kandungan kolesterol dalam berbagai bahan makanan hewani. Pusat Penelitian dan Pengembangan Gizi, Badan Litbangkes. 27(1): 224-230.
Santoso, J. Nurjannah, dan A. Irawan. 2014. Kandungan dan kelarutan mineral pada cumi-cumi Loligo sp. dan udang vannamei Litopenaeus vannamei. Jurnal Ilmu Perairan dan Perikanan Indonesia. 15(1):7-12.

Sasaki, J, K. Ishita, K. Takaya, Y. Uchisawa, and H. Matsue. 1997. Antitumor activity of squid ink. Journal of Nutrition Science Vitaminology. 43:455461.

Sudjoko B. 1988. Cumi-cumi (Cephalopoda, Molusca) sebagai Salah Satu Bahan Makanan dari Laut. Oseana XII 3(3): 97-107.

Zhong, J. P. G. Wang, J. H. Shang, J. Q. Pan, K. Li, Y. Huang and H. Z. Liu. 2009. Protective effects of squid ink extract towards hemopoieticinjuries induced by cyclophosphamine. Marine Drugs. 7: 9-18

Wink, M. 2008. Ecological Roles of Alkaloids. in: Wink, M. (Eds.) Modern Alkaloids, Structure, Isolation Synthesis and Biology. Wiley-VCH Verlag GmbH \& Co. KgaA. Jerman: $378-411$ 